\title{
The Effect of Experience Value on Private Brand Purchase Intention
}

\author{
Meizhen Zhang, Qing Li, Defeng Yang \\ School of Management, Jinan University, Guangzhou, China \\ Email: xiangnibaicai@163.com
}

Received 13 October 2014; accepted 6 October 2015; published 9 October 2015

Copyright (C) 2015 by authors and Scientific Research Publishing Inc.

This work is licensed under the Creative Commons Attribution International License (CC BY). http://creativecommons.org/licenses/by/4.0/

c) (i) Open Access

\begin{abstract}
Under the experience economical time background, brand experience has attracted a lot of attention in marketing practice. In this article, we explore the effect of experience value on consumers purchase intention of private brands and examine the moderating effects of private label tier, purchase degree and BRIC.
\end{abstract}

\section{Keywords}

Experience Value, Private Brands, Purchase Intention, Private Label Tier, Purchase Degree, BRIC

\section{Introduction}

Nowadays, many retailers such as Watsons try their best to sell private brands to get profits and foster customers' loyalty. Therefore, it is a critical issue for retailers to improve consumers' purchase intention of private brand. Some scholars have revealed that price and the environment of shopping can affect consumers' purchase intention of private brands, while little is known about the other antecedents of consumers' intention to purchase private brands, the purpose of this article is to conduct a study to address the issues. Under the experience economical time background, it is increasingly important that consumers can perceive experience value while shopping. For retailers, they should create conditions for consumers to perceive experience value when they purchase private brands. On the basis of prior research, experience value consists of several dimensions, such as functional value, emotional value and social value. However, little is known about the values driving different consumers to buy different kinds of store brands.

According to consumers purchase share of store brand, Ailawadi divided consumers into three categories: light store-brand user, medium user and heavy user [1]. According to Yang et al., these three different kinds of consumers also differ in price sensitivity and quality sensitivity [2]. Thereby, we expect that the purchase degree for private brand will moderate the relationship between experience value and purchase intention. 
Lamey divided store brands into three tiers and Steiner divided them into two tiers [3] [4]. On the basis of previous researches, Yang and Wang divided store brands into three tiers: low-price tier, medium-price tier, and high-premium tier. Low-price tier store brand has acceptable quality and the lowest price; medium-price tier has the quality equal to national brand but it is cheaper than national one; high-premium tier has high quality and high premium. It is not lower than national brands in quality and price respectively [5]. Retailers should prefer different pricing strategy to different store brands. In consideration of the marketing costs, we consider it is necessary to explore the effect of experience value on consumers purchase intention of private brands and examine the moderating effect of private label tier. That is, which kind of experiences should retailers create when consumers purchase store brand in low-price tier, in medium-price tier or in high-premium tier. Retailers can prefer different marketing strategies to create experience environments for different store brands.

The conditions for successful brand building are not equally favorable across categories [6]. Since private label products are cross categories, it is important to know customers' predispositions toward brands while buying. BRIC is shorted for brand relevance in category, which measures the overall role of brands in customers' decision making in a specific category [6]. BRIC is a customer-oriented construct that measures such differences in the role of brands in customer decision making. Thus it focuses on the category not the individual brand [6]. In this article, we will examine the moderating effect of BRIC on the relationship between experience value and purchase intention of private brands.

We address four clusters of research questions. First, how does experience value do effect on consumers purchase intention of store brands? Second, which experience should retailers provide to store brands positioned in different tiers? Third, whether purchase degree will moderate the effect of experience value on purchase intention? Fourth, whether BRIC will moderate the effects as well?

\section{Theoretical Analysis Framework}

In this study, we propose that consumers' intention to buy private brands can be influenced in the process of experience. Brakus, Schmitt and Zarantonello thought that experience can be divided into short-lived and longlasting experiences [7]. Short-lived experiences occur spontaneously without much reflection and the long-lasting experiences occur deliberately and stored in consumer memory, then will affect consumer satisfaction and loyalty [8] [9]. That is, retailers can provide deliberately consumers an experience environment while shopping. According to elaboration likelihood model, attitude will be influenced by Peripheral path, such as the environment. Besides, through the experiences, consumers will recognize private brands and set aside some of the presuppositions about them, for example, most consumers thought that private brands have inferior qualities compared with manufacturers' brands.

Sprott and Shimp stated that consumers perceived the qualities of private brands highly while trying the products [10]. Dick, Jain and Richardson found that one of the reasons why consumers don't want to buy private brands is that they are not familiar with the private brands [11]. Whereas, experience can enhance brand awareness and brand knowledge. This study tries to explore the impact path of consumers' intention of purchasing private brands, in experience terms. In the process of consumption experience, consumers can get experience value. This study is to explore the key value that consumers can perceive through buying store brands in different tiers and to examine the effect of experience and experience value on consumers' intention to purchase private brands. In addition, the effect will be moderated by the purchase degree, private label tier and BRIC (See Model 1).

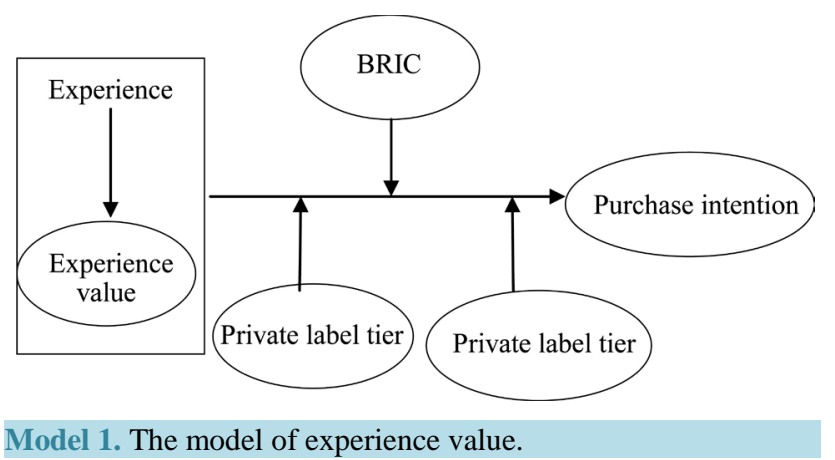




\section{Path Analysis}

\subsection{The Effect of Experience}

There are many kinds of experiences which occur when consumers search for products, when they shopping and get service, or when they consume the products [7] [12] [13]. In brief, there are four kinds of experiences: product experience, shopping and service experience, consumption experience and brand experience. Hoch and Brakus, Schmitt and Zarantonello thought that product experiences occur when consumers interact with the products, and shopping experiences occur when they interact with the store's environment [7] [14]-[16]. Consumption experiences occur when consumers consume products and brand experiences occur when consumers consume brands [7].

In conclusion, experiences occur in the process of shopping. Generally, at the first phrase, consumers enter a store and interact with the environment and salespeople, then the shopping experiences occur. At the second phrase, consumers search for the products they want and compare different brands, and then product experiences occur. At the third phrase, consumers touch or foretaste the products if permitted, and then consumption experiences occur. However, the order of the three phrases is not invariable.

This research focuses on how to increase sales of private brands. We discuss experiences at first. While experiencing the products, consumers can perceive experience value at the same time.

\subsection{The Effect of Experience Value on Purchase Intention}

Pine and Gilmore pointed out that experiences are a distinct economic offering, as distinct from services as services are from goods [17]. Until now, experience value has been divided into different dimensions according to different scholars' researches. For example, Brengman and Geuens and Pine and Gilmore suggested that experience value includes four dimensions: intrinsic and extrinsic value, active and reactive value [17] [18]. Zhang and You considered that experience value consists of three dimensions: functional value, emotional value and social value [19]. Nevertheless, private brand is special product which is different from manufacturer' brand. It is characterized by value and price. So we consider that private brand' experience value includes three dimensions, that is, functional value, emotional value and intellectual value [20].

Functional value means that consumers can get perception utility via functional, practical and physical attributes provided by consumption products. Private brand is provided by retailers, consumers are linked to the retailers, while buying private brands. That is, consumers can get emotional value from the store as well as private brand. Intellectual value means that consumers can get perception utility because of curiosity and knowledge of private brand while evaluate them [20].

Experience value makes consumers be familiar with the private brands, so as to change the way many consumers think about private brands. We propose that experience value, including functional value, emotional value and intellectual value can influence consumers purchase intention while buying private brands.

\subsection{The Moderating Effects}

\subsubsection{Purchase Degree}

Ailawadil, Pauwels and Steenkamp divided consumers buying private labels into three groups according to PL (private label) share exhibited by consumers: Low $(<20 \%)$, medium (20\% - 60\%), and high ( $>60 \%)$ PL share [1]. Their research finds that low PL share is associated with lower grocery spending. These consumers seem to be "NB cherry pickers," with significantly higher brand loyalty and quality consciousness; Heavy PL buyers appear to be more likely to focus on saving money. Singh, Hansen, and Blattberg show that, among a retailer's customers, heavy PL users are more likely to switch to Wal-Mart when it enters the area [21]. In conclusion, low PL buyers are brand-oriented or quality-oriented while heavy PL buyers are price-oriented. For consumers priceoriented, they compare the different brands usually, they want retailers to build an environment in which they can compare the prices easily. For consumers brand-oriented, they are more willing to harmonious and nice environment while shopping to highlight the quality of the store and the private brands.

We propose that purchase degree will moderate the effect of experience value on purchase intention. For heavy PL buyers, their purchase intention of private brands will be stronger when they perceive functional value than emotional value or intellectual value. For low PL buyers, emotional value or intellectual value can enhance their purchase intention compared to functional value. 


\subsubsection{Private Label Tier}

According to Yang and Wang, low-price tier store brand has acceptable quality and the lowest price [5]; medium-price tier has the quality equal to national brand but it is cheaper than national one; high-premium tier has high quality and high premium. As Wei et al. have proposed that high perception matching can significantly influence consumers' valuation [22]. Perceiving the characteristic of the store brand fit the experience value can promote consumers brand valuation, and then improve their purchase intention. In conclusion, we propose that for low-price tier store brand, functional value rather than emotional value or intellectual value will affect consumers purchase intention positively. While for high-premium tier, the impact path of emotional value or intellectual value on purchase intention is stronger.

\subsubsection{BRIC}

The person with higher BRIC attaches great importance to brand while making purchasing decision. As cue utilization theory put it, brands can serve as an important signal to reduce perceived risk. The research of Fischer, Volckner and Sattler finds that brand functions can have great effects on BRIC and BRIC can affect brand loyalty, self-brand connection and brand equity [6]. That is, BRIC is an important construct for retailers to build loyalty and improve brand equity. Compared to manufacturer' brand, private brand has lower image and popularity. Hence, even though private brand is characterized by high quality and low price, it can hardly attract consumers with high BRIC. That is, BRIC will moderate the effect of experience value on purchase intention negatively.

\section{Conclusions and Suggestions}

As stated, an experience environment can make consumers perceive experience values, which have positive effects on consumers purchase intention of store brands. Experience occurs when consumers search, shop and try out the products, therefore, retailers should create experience environment throughout the shopping process. Then experience values can be perceived by consumers, such as functional value, emotional value and intellectual value, which will improve consumers' intention of buying private brands. According to our framework, retailers should create an experience environment for consumers while shopping. For example, consumers can be allowed to taste or use the store brands for free. Certainly, the environment of the store should be decorated tidy and comfortable and salespeople should be polite and passionate. Private brands should be showed conspicuously and presented appropriately.

In addition, purchase degree moderates the effect of experience value on consumers purchase intention of private brands. Comparatively speaking, High PL buyers regard the price of products as the most important factors while purchasing and low PL buyers give more are weight to brand or quality. Hence retailers should prefer different strategies to attract different consumers. Specifically, retailers can put the same kinds of products nearby and price them clearly so that consumers can compare them easily. With this measure, High PL buyers' purchase intention will improve. They can build a long good cooperation relationship with low PL customers, for example, retailers can set up membership card and give some preferences to strengthen emotional value.

According to our framework, private label tier moderates the effect of experience value on consumers purchase intention of private brands as well. For low-price tier store brand, retailers should promote and put emphasis on the functional value. For example, they can list the functions of low-price store brands on the products' label. For high-premium tier, emotional value or intellectual value can improve consumers purchase intention. The conditions of shopping should be able to create emotional resonance.

BRIC means that consumers attach great importance to brand while making purchase decision, owing to less propaganda, private brand is unbeknown and has less awareness. We expect that BRIC will negatively moderate the effect of experience value on consumers' intention of buying private brands. Thereby, we suggest that consumers should improve the shopping environment to make consumers feel more comfort and improve the perceived quality of the store and private brands.

We have to admit that, it is difficult for private brands to build intellectual value. Private brands still have a long way to build their own "brand".

\section{References}

[1] Ailawadi, K.L., Pauwels, K. and Steenkamp, J.B.E.M. (2008) Private-Label Use and Store Loyalty. Journal of Mar- 
keting, 72, 19-30. http://dx.doi.org/10.1509/jmkg.72.6.19

[2] Yang, D.F., Li, Q., Zhang, P. and Wei, H.Y. (2012) The Relationship among Customer-Retailer Affection, Mianzi Consciousness and Purchase Intention of Retailer's Store Brand. Finance \& Trade Economics, 8, 97-104.

[3] Lamey, L., Deleersnyder, B., Dekimpe, M.G. and Steenkamp, J.B.E.M. (2007) How Business Cycles Contribute to Private-Label Success: Evidence from the United States and Europe. Journal of Marketing, 71, 1-15. http://dx.doi.org/10.1509/jmkg.71.1.1

[4] Steiner, R.L. (2004) The Nature and Benefits of National Brand/Private Label Competition. Review of Industrial Organization, 24, 105-127. http://dx.doi.org/10.1023/B:REIO.0000033351.66025.05

[5] Yang, D.F. and Wang, X.X. (2008) Effect of Perceived Quality, Perceived Value, Brand Knowledge and Attitude of 2-Tier Store's Own Label Products and Store Loyalty. Journal of Marketing Science, 4, 69-85.

[6] Fischer, M., Volckner, F. and Sattler, H. (2010) How Important Are Brands? A Cross-Category, Cross-Country Study. Journal of Marketing Research, 47, 823-839. http://dx.doi.org/10.1509/jmkr.47.5.823

[7] Brakus, J.J., Schmitt, B. and Zarantonello, L. (2009) Brand Experience: What Is It? How Is It Measured? Does It Affect Loyalty? Journal of Marketing, 73, 52-68. http://dx.doi.org/10.1509/jmkg.73.3.52

[8] Oliver, R.L. (1997) Satisfaction: A Behavioral Perspective on the Customer. New York.

[9] Reinchheld, F. (1996) The Loyalty Effect: The Hidden Force Behind Growth, Profits, and Lasting Value. Long Range Plann, 29.

[10] Sprott, D.E. and Shimp, T.A. (2004) Using Product Sampling to Augment the Perceived Quality of Store Brands. Journal of Retailing, 80, 305-315. http://dx.doi.org/10.1016/j.jretai.2004.10.006

[11] Dick, A., Jain, A. and Richardson, P. (1995) Correlates of Store Brand Proneness: Some Empirical Observations. Journal of Product \& Brand Management, 4, 15-22. http://dx.doi.org/10.1108/10610429510097663

[12] Arnould, E.J., Price, L. and Zinkhan, G.M. (2002) Consumers. McGraw-Hill, Boston.

[13] Holbrook, M.B. (2000) The Millennial Consumer in the Texts of Our Times: Experience and Entertainment. Journal of Macromarketing, 20, 178-192. http://dx.doi.org/10.1177/0276146700202008

[14] Hoch, S.J. (2002) Product Experience Is Seductive. Journal of Consumer Research, 29, 448-454. http://dx.doi.org/10.1086/344422

[15] Hui, M.K. and Bateson, J.E.G. (2002) Perceived Control and the Effects of Crowding and Consumer Choice on the Service Experience. Journal of Consumer Research, 18, 174-184.

[16] Kerin, R.A., Jain, A. and Howard, D.J. (1992) Store Shopping Experience and Consumer Price-Quality-Value Perceptions. Journal of Retailing, 68, 376-397.

[17] Pine, B.J. and Gilmore, J.H. (2002) Welcome to the Experience Economy. Harvard Business Review, 76, 97-105.

[18] Brengman, M. and Geuens, M. (2003) The Four Dimensional Impact of Color on Shoppers' Emotions. Working Papers of Faculty of Economics and Business Administration, Ghent University, Belgium, 59-69.

[19] Zhang, F.C. and You, S.X. (2009) Reviewing the Theoretical Models of Experience Value Structure Dimensions. Foreign Economics and Management, 46-52.

[20] Sheth, J.N., Newman, B.I. and Gross, B.L. (1991) Why We Buy What We Buy: A Theory of Consumption Values. Journal of Business Research, 22, 159-170. http://dx.doi.org/10.1016/0148-2963(91)90050-8

[21] Singh, V.P., Hansen, K.T. and Blattberg, R.C. (2006) Market Entry and Consumer Behavior: An Investigation of a Wal-Mart Supercenter. Marketing Science, 25, 457-476. http://dx.doi.org/10.1287/mksc.1050.0176

[22] Wei, H., Song, X.B. and Yuan, Y.D. (2013) Research on Mechanism of Influence of Perception Matching and Invoivement on Brand. Extension Evaluation, 30, 796-800. 